\title{
Systematic studies in Dracophyllum (Epacridaceae) 1. Morphometric analyses of Dracophyllum secundum sensu lato
}

\author{
N. Streiber, E.A. Brown, B.J. Conn and C.J. Quinn
}

\begin{abstract}
Streiber, N. ${ }^{1}$, Brown, E.A. ${ }^{2}$, Conn, B.J. ${ }^{2}$ and Quinn, C.J. ${ }^{1}$ ('School of Biological Science, University of New South Wales, Sydney, NSW 2052, Australia; ${ }^{2}$ Royal Botanic Gardens, Mrs Macquaries Road, Sydney, NSW 2000, Australia) 1999. Systematic studies in Dracophyllum (Epacridaceae) 1. Morphometric analyses of Dracophyllum secundum sensu lato. Telopea 8(3): 381-391. An evaluation of the morphological variation within the New South Wales taxon Dracophyllum secundum revealed the following two undescribed distinct taxa: D. sp. 'Jervis Bay' (Brown 97/80) and D. sp. 'Lansdowne' (Brown 97/51). The morphological differences between the taxa used in the analyses are summarised.
\end{abstract}

\section{Introduction}

Dracophyllum Labill. comprises approximately 50 species, with 35 in New Zealand (Allan 1961), seven in New Caledonia (Virot 1975) and five in Australia. Together with its allies Richea and Sphenotoma, it forms a well-defined group within the epacrid lineage (Powell et al. 1996; Crayn et al. 1998). Dracophyllum is currently divided into three subgenera (Oliver 1928): Oreothamnus (flowers solitary or in a simple raceme), Dracophyllum (as 'Eudracophyllum' in Oliver; flowers in panicles) and Cordophyllum (flowers in dense fascicles, each on a separate densely bracteose pedicel). All taxa included in this study belong to the subgenus Dracophyllum.

The Australian taxa are endemic, although some close relatives are found in New Zealand (e.g. D. strictum Hook.f., D. latifolium A.Cunn.) and New Caledonia (D. verticillatum Labill.). Prior to this study, the following species were recognised in Australia: D. milliganii Hook.f. and D. minimum F. Muell. (Tasmania), D. sayeri F. Muell. (Cook District, Queensland), D. fitzgeraldii C. Moore \& F. Muell. (Lord Howe Island) and Dracophyllum secundum R.Br. (mainland New South Wales).

Dracophyllum secundum sensu lato is a common and widespread taxon (Fig. 1) that has long been recognised as morphologically very variable. Powell (1992) recommended that this taxon receive further investigation. Recent collections, particularly from the Comboyne Plateau area of northern New South Wales, also suggested that the current classification did not adequately accommodate the morphological variation observed. This study aimed to investigate the morphological variability within Dracophyllum secundum using morphometric techniques.

\section{Methods}

The measurements of morphological characters for the numerical analyses were made from 69 collections (51 herbarium and 18 living; including three herbarium specimens of $D$. sayeri and three of $D$. fitzgeraldii). Since the aim of this study was to evaluate morphological variability within $D$. secundum sensu lato, only a small number of 
specimens of $D$. fitzgeraldii and D. sayeri (available at NSW and UNSW) was added to the analysis as reference taxa. These latter two species enabled the taxonomic significance of morphological variation within $D$. secundum sensu lato to be evaluated. Furthermore, the superficial similarity between $D$. fitzgeraldii and the Jervis Bay populations of D. secundum had been noted by several field workers (e.g. J. Benson 1999, pers. comm.). The inclusion of Dracophyllum sayeri allowed a superficial comparison of the morphological features of this species and D. fitzgeraldii. Since adequate material of related New Caledonian and New Zealand species was not readily available, these taxa were not included in the analyses. Specimen details are given in Appendix 1.

\section{Morphological characters}

Initially 140 morphological characters (J.M. Powell, unpublished) were assessed. Twenty-six of these characters (Table 1) were used for the various analyses of this study. The remaining characters were discarded because they were either more or less invariant amongst the taxa under investigation or were difficult to quantify for morphometric analysis (e.g. bract margin and nectary margin).

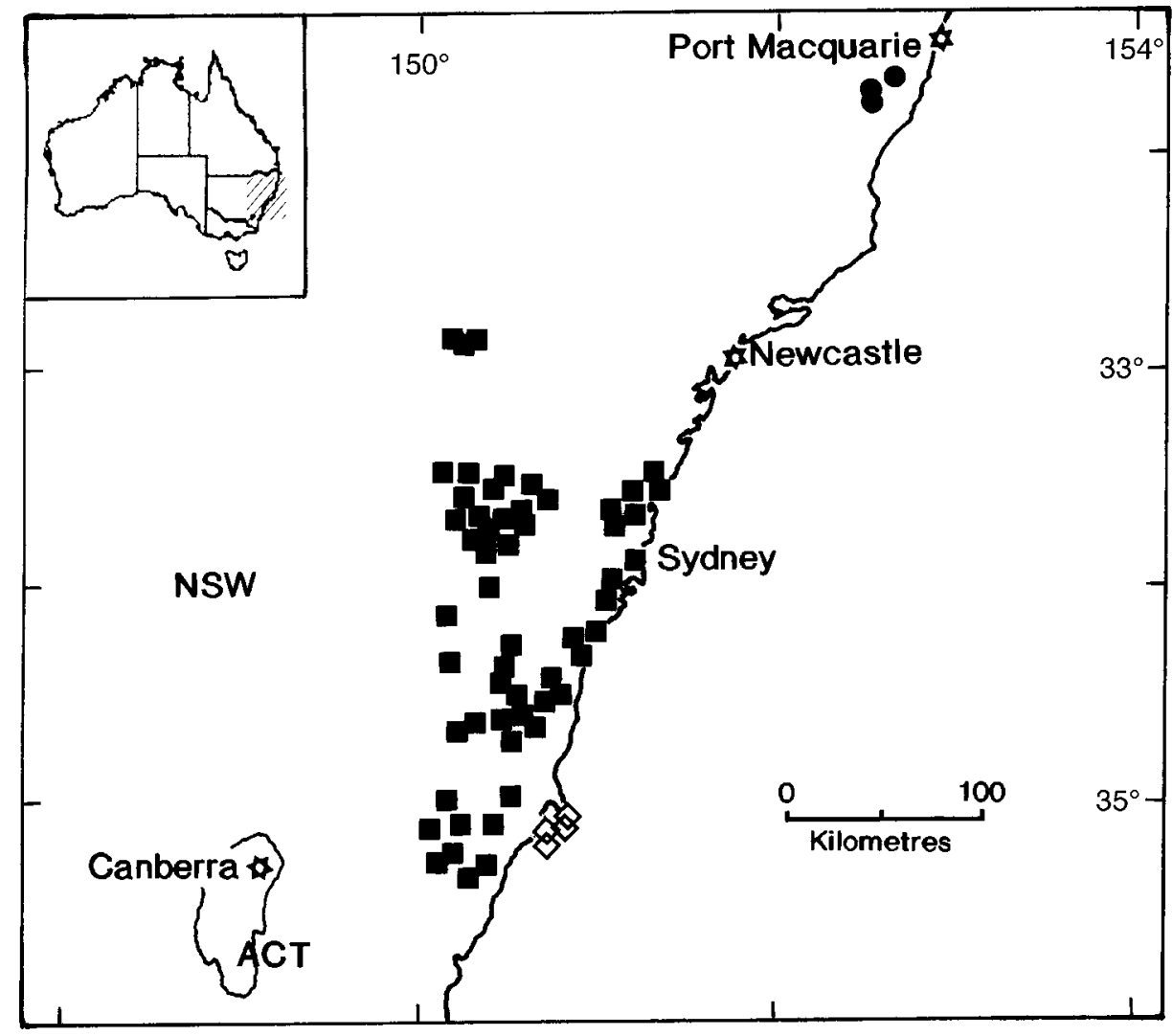

Fig. 1. Distribution of Dracophyllum in mainland New South Wales. $\mathbb{D}$ Dracophyllum secundum; $\diamond D$. sp. 'Jervis Bay' (Brown 97/80); $\otimes D$. sp. 'Lansdowne' (Brown 97/51). Note: to maintain clarity, not all collections are graphically presented. 
Table 1. Final character set used in the morphometric analyses, with alphabetic codes (as used in Figs 2,3 ) and character states recognised.

\begin{tabular}{|c|c|c|}
\hline Code & Character & State \\
\hline anl & anther length & $(\mathrm{mm})$ \\
\hline \multirow[t]{2}{*}{ anp } & anther position & $\begin{array}{l}\text { (1) fully exserted from corolla tube } \\
\text { (2) within throat }\end{array}$ \\
\hline & & (3) within corolla tube \\
\hline asa & $\begin{array}{l}\text { staminal filament attachment } \\
\text { to corolla }\end{array}$ & $\begin{array}{l}\text { (1) in upper half of corolla tube } \\
\text { (2) at base of corolla tube }\end{array}$ \\
\hline \multirow[t]{2}{*}{ bas } & bracts apex shape & (1) acute \\
\hline & & (2) blunt \\
\hline \multirow[t]{2}{*}{ bos } & bracts outer surface & (1) glabrous \\
\hline & & (2) hairy \\
\hline cll & corolla lobe length & $(\mathrm{mm})$ \\
\hline $\mathrm{clw}$ & corolla lobe width & $(\mathrm{mm})$ \\
\hline $\mathrm{ctl}$ & corolla tube length & $(\mathrm{mm})$ \\
\hline $\mathrm{ctr}$ & corolla lobe length: tube length ratio & \\
\hline ctw & corolla tube width & $(\mathrm{mm})$ \\
\hline \multirow[t]{3}{*}{$\mathrm{cvk}$} & corolla tube length vs. calyx length & (1) exceeding calyx \\
\hline & & (2) \pm equal to calyx \\
\hline & & (3) shorter than calyx \\
\hline \multirow[t]{2}{*}{ fma } & direction of flower maturation & (1) from base to apex \\
\hline & in inflorescence & (2) from apex to base \\
\hline \multirow[t]{3}{*}{ fsn } & number of flowers per node & (1) 1 or 2(or 3)-flowered \\
\hline & (at base of inflorescence) & (2) 4-10(-11)-flowered \\
\hline & & (3) >10-flowered (often 20-35) \\
\hline \multirow[t]{3}{*}{ fst } & number of flowers per node & (1) 1 or 2 (or 3)-flowered \\
\hline & (halfway up inflorescence) & (2) 4-10(-11)-flowered \\
\hline & & (3) >10-flowered (often 20-35) \\
\hline \multirow[t]{4}{*}{ hab } & habit & (1) low \pm prostrate shrub \\
\hline & & (2) spreading to laxly erect shrub \\
\hline & & (3) erect shrub \\
\hline & & (4) tree \\
\hline hgt & plant height & $(\mathrm{cm})$ \\
\hline $\mathrm{klm}$ & calyx length & $(\mathrm{mm})$ \\
\hline kwm & calyx width & $(\mathrm{mm})$ \\
\hline \multirow[t]{2}{*}{ las } & leaf apex shape & (1) acute \\
\hline & & (2) blunt \\
\hline$\| \mathrm{m}$ & leaf length & $(\mathrm{mm})$ \\
\hline Ims & leaf margin & number of lobes per $5 \mathrm{~cm}$ \\
\hline \multirow[t]{2}{*}{ Ish } & leaf surface & (1) glabrous \\
\hline & & (2) hairy \\
\hline Iwm & leaf width (at midpoint of leaf) & $(\mathrm{mm})$ \\
\hline ovr & ovary length:width ratio & \\
\hline \multirow[t]{3}{*}{ pph } & peduncle/pedicel surface & (1) glabrous \\
\hline & & (2) hairs $<0.2 \mathrm{~mm}$ long \\
\hline & & (3) hairs > $0.5 \mathrm{~mm}$ long \\
\hline stl & style length & $(\mathrm{mm})$ \\
\hline
\end{tabular}


Those characters that require further explanation are briefly discussed below.

\section{Leaves}

Leaf length $(l l m)$ and width $(l w m)$ were measured on leaves that were inserted approximately $10 \mathrm{~cm}$ below the branch apex.

\section{Leaf margin}

The leaf margin $(l m s)$ varies from entire to minutely lobed. The lobes are either terminated by a tooth or the tooth is absent. Although the lobes vary in form from bulbous at the base to tapered, it was the presence or absence of the basal lobe that was scored, rather than the variations in morphology, which are difficult to quantify.

\section{Inflorescence}

The inflorescences of the Australian species are variously modified superconflorescences with the conflorescence axis reduced to 1-many bracteose eubotryoids on anthotelic short shoots (sensu Briggs \& Johnson 1979). The uniflorescence is usually a 3- to manyflowered eubotryoid (sometimes reduced to a single flower). Although the inflorescence is described as bracteose, the bracts and bracteoles are caducous, their presence often being indicated only by a scar. The superconflorescences of all Australian taxa, except the 'Lansdowne' group, mature along the main axis in acropetal sequence (fma). Maturation in the 'Lansdowne' group is basipetal.

The number of flowers at each node varies according to position on the inflorescence, basal nodes tending to have more flowers than distal nodes. To ensure that number of flowers per inflorescence provided comparable information for all taxa in this study, two measurements were taken, namely number of flowers per basal inflorescence node $\left(f_{s} n\right)$, and number of flowers per node from the middle of the inflorescence $(f s t)$. Because the lowest node could not always be scored on specimens due to obscuring by leaves and flowers, the 'basal' node was scored from one of the three lowest nodes. The 'middle' node is the node nearest to the mid-point of the inflorescence length that could be measured.

An initial evaluation of the taxa using the character 'number of flowers per node' as a measure of similarity indicated that inflorescences of taxa are mostly few-flowered per node (1-3 flowers) or many-flowered per node ( $>10$ flowers, usually $>25)$, with fewer taxa having a medium number of flowers per node (4-10). Taken together with the difficulty of accurately counting the number of flowers in highly floriferous inflorescences, it was decided to categorise the data into discrete range values for analysis. Although this type of range standardisation results in a reduction of information, this technique was also used to reduce the influence (hence, weighting) of the strongly bimodal distribution of values.

\section{Flowers}

The perianth, androecial and gynoecial measurements are all based on an average of five flowers.

\section{Anther position}

The anthers are recorded as:

- fully exserted, when the entire locule is exserted beyond the base of the corolla lobes;

- partially exserted, when only part of the anther is positioned above the base of the corolla lobes;

- included, when no part of the anther protrudes beyond the corolla tube. 


\section{Ovary length/width ratio}

The measurements for ovary length or width showed highly skewed or anomalous distributions. This was assumed to be a consequence of the variation in age of the ovaries measured. However, the ratio of ovary length to its width does not appear to vary with age (when measured within an individual inflorescence).

\section{Data analysis}

The data were analysed using PATN version 3.5 (Belbin 1993). Two main types of quantitative analysis were used: ordination and cluster analysis. Multidimensional scaling (MDS) was used in the ordination with Gower's metric association measure. The relationship of these morphometric variables across the ordination space (derived from MDS) was evaluated using principal axis correlation (PCC) procedures. For the cluster analysis a hierarchical classification was produced using Gower's metric association measure together with Flexible UPGMA. The phenograms summarising the results of group fusion were produced using DEND and the groups were defined using the group definition program (GDEF). The rationale for the use of these multivariate techniques, as well as their limitations and mathematical properties, have been discussed in a number of publications (e.g. Belbin 1993, Brown \& Wiecek 1996, Crisp \& Weston 1993, Gower 1971).

\section{Results and Discussion}

The 3-dimensional ordinations are presented in Figures 2 and 3. The character vector diagrams, derived from PCC, have been included. These vectors indicate the correlation of the characters across the ordination space. The vector lengths indicate the relative correlation coefficients. All measurements given below refer only to specimens used in the analysis.

The initial results from cluster analysis of 69 specimens and 26 characters show that the specimens formed six well-defined groups (refer to both Figs 2 and 3); namely, D. sayeri, D. fitzgeraldii, D. sp. 'Jervis Bay' (Brown 97/80), 'Avon River', D. sp. 'Lansdowne' (Brown 97/51), and D. secundum sensu stricto. The latter four groups are presently included in $D$. secundum sensu lato. Although D. fitzgeraldii is apparently indistinctly clustered from D. secundum on the first two ordination vectors (Fig. 2), it is obviously distinctly clustered in the ordination space characterised by vectors 1 and 3 (Fig. 3). Likewise, Dracophyllum sp. 'Lansdowne' (Brown 97/51) and D. secundum are not separable on vectors 1 and 3 (Fig. 3), but are readily distinguishable on vectors 1 and 2 (Fig. 2). A consideration of the ordination space summarised by vectors 1, 2 and 3 (vectors 2 and 3 not presented here), shows that the Jervis Bay populations clearly cluster with $D$. fitzgeraldii and $D$. sayeri (also refer group fusion phenogram, Fig. 4). Similarly, D. secundum, 'Avon River' and D. sp. 'Lansdowne' distinctly cluster, separate from the previous group (also shown in Fig. 4).

\section{(1) Dracophyllum secundum sensu stricto}

This species is distinguishable from D. sp. 'Jervis Bay' (Brown 97/80), D. fitzgeraldii and $D$. sayeri by several characteristics, but particularly by tending to have more teeth on the leaf margin (lms: 8-17(-32) teeth per $5 \mathrm{~cm})$, smaller and narrower leaves $(\mathrm{llm}$ and lwm: (33-)63-110(-170) $\mathrm{mm}$ and (1.5-)2.5-4.5(-6) $\mathrm{mm}$, respectively), and fewer flowers at the midpoint of the inflorescence (fst: 1-3 flowers, rarely to 11). Furthermore, this species differs from D. sp. 'Lansdowne' (Brown 97/51) by being a smaller shrub (hab), with smaller flowers ( $\mathrm{anl}, \mathrm{ctl}, \mathrm{clw}, \mathrm{cll}, \mathrm{klm}, \mathrm{kwm}, \mathrm{stl})$, as discussed under $D . \mathrm{sp}$. 
'Lansdowne' (Brown 97/51). In addition, there is a greater variation in the number of flowers at the basal inflorescence nodes $(f s n)$, namely 1-3-flowered, less frequently to 10 (or rarely 11) compared with 1-3(or 4) in D. sp. 'Lansdowne' (refer character vector diagrams of Figs 2, 3).

The specimens of $D$. secundum sensu stricto are grouped into four morphological subgroups. One of the more distinctive subgroups (' $K$ ' of Figs 2, 3,4) refers to three pink-flowered plants from Kellys Falls (Helensburgh, N.S.W.; $34^{\circ} 12^{\prime}$ S, $150^{\circ} 58^{\prime} \mathrm{E}$ ) that are characterised by a tendency to have more lobes on the leaf margin (lms) and slightly larger, more numerous flowers $(c t l, s t l, f s n)$ than the other subgroups. However this subgroup and all others (refer Fig. 4) do not appear to correlate with any ecological or geographic variables. The clustering appears to be somewhat random, with plants from one population often separated into different subgroups (as occurs with a fourth Kellys Falls specimen).

\section{(2) The 'Avon River' entity}

This is represented by a single specimen (Thomas s.n., NSW 363452) from the Woronora River catchment (Central Coast, N.S.W; 34⒉ 4 'S, 150 $43^{\circ}$ 'E) ('A' of Figs 2, 3, 4). The main morphological difference between this specimen and D. secundum sensu stricto is that it is sparsely and evenly covered with long soft hairs (cf. D. secundum

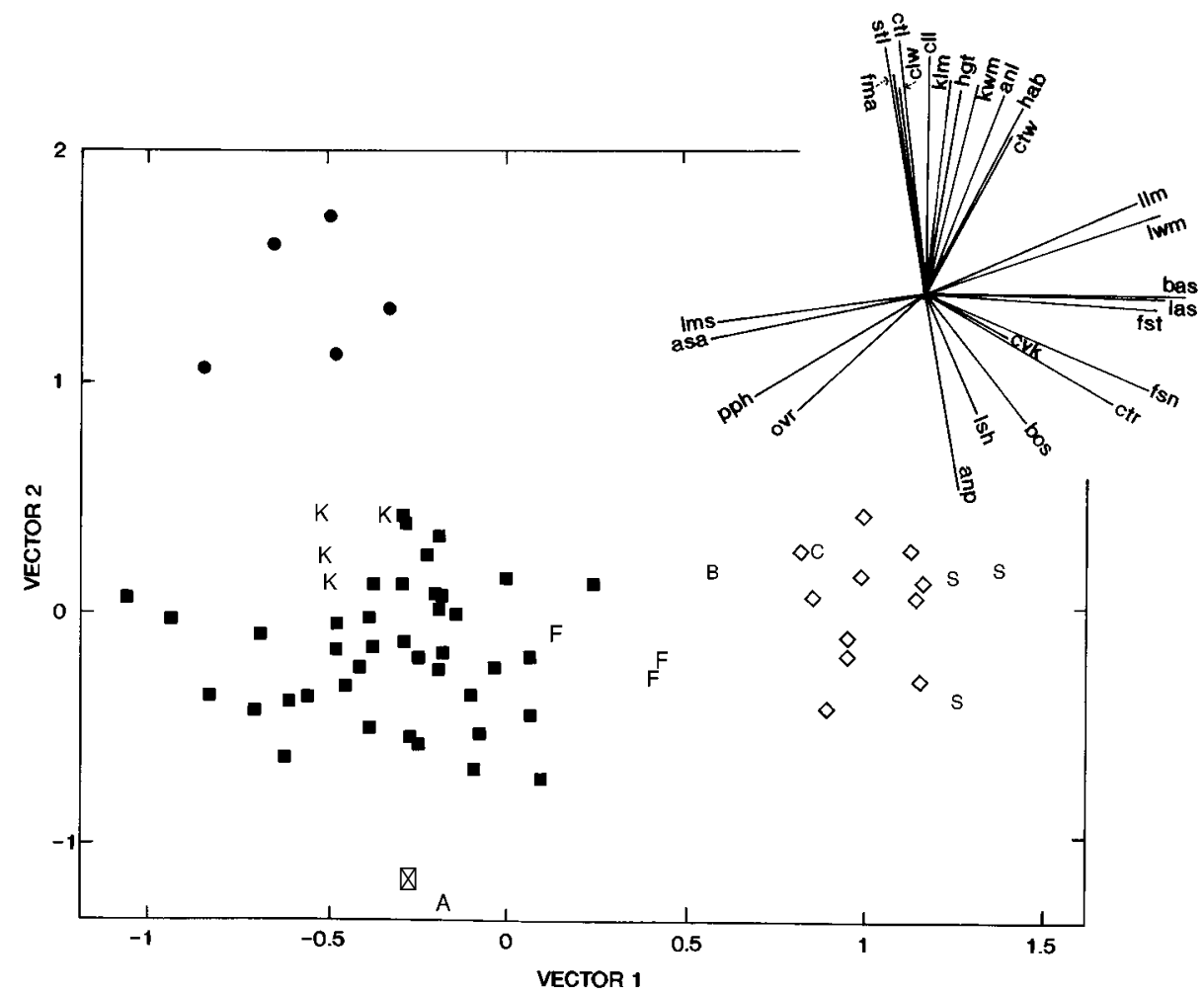

Fig. 2. Three-dimensional ordination of the specimens onto the $1^{\text {st }}$ and $2^{\text {nd }}$ vector axes and the character vector diagram. $\otimes$ Dracophyllum secundum; K Kellys Falls population of D. secundum; A 'Avon River' specimen; $\diamond$ D. sp. 'Jervis Bay' (Brown 97/80); B Brown 97/83S (shade branch of Brown 97/83), 'Jervis Bay' group; C Brown 97/83, 'Jervis Bay' group; $\otimes D$. sp. 'Lansdowne' (Brown 97/51); F D. fitzgeraldii; $\mathbf{S}$ D. sayeri. 
sensu stricto which is glabrous), and it tends to have shorter and narrower leaves than typical D. secundum (llm and lwm: c. $33 \mathrm{~mm}$ long and $2 \mathrm{~mm}$ wide, respectively). Three dimensional ordination with the indumentum characters of the leaf and bracts deleted reduced but did not eliminate the distinctness (Fig. 4) of the Avon River specimen from the nominate group (cluster analysis not presented here). However, the taxonomic status of this entity requires further evaluation with more adequate sampling. This is particularly relevant because D. secundum sensu stricto is still morphologically variable. For example, flowering (hence, apparently mature) plants are sometimes very small and seedling-like. Likewise, plants sometimes produce side branches with very small leaves on an otherwise typical stem. Since the biology of these plants and the extent of environmental influences are largely unknown, interpretation of such material is problematic. In addition, the production of hairs in some epacrid taxa appears to result from simple mutations that may occur relatively frequently (Brown \& Wiecek 1996). Attempts to re-collect specimens from the Avon River area have been largely unsuccessful: a similar specimen has been reported from an adjacent catchment area (D. Thomas pers. comm.) and one recent sterile collection (M. Robinson pers. comm.) also appears to belong to this taxon. Since only inadequate or insufficient material is available, this entity has been tentatively included in D. secundum.

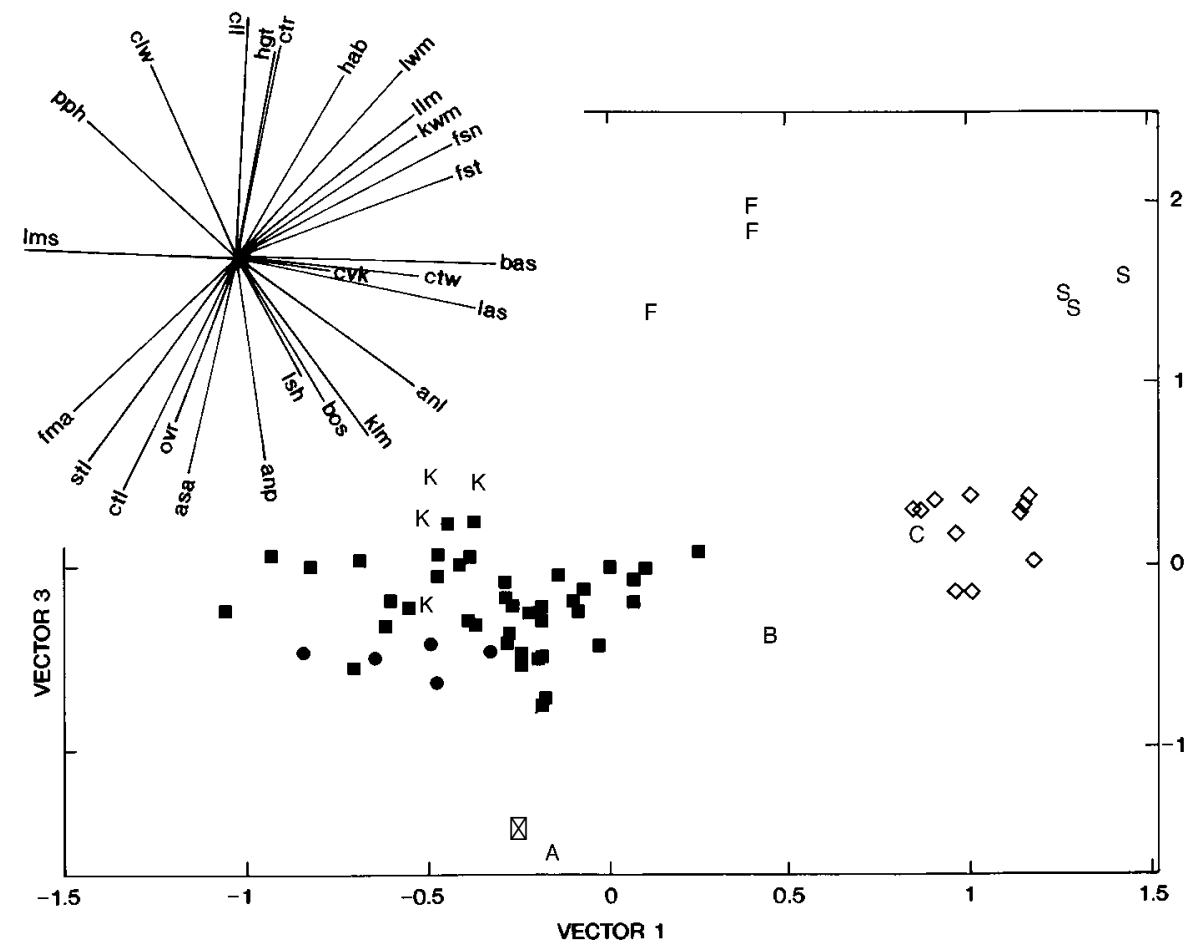

Fig. 3. Three-dimensional ordination of the specimens onto the $1^{\text {st }}$ and $3^{\text {rd }}$ vector axes and the character vector diagram. $\otimes$ Dracophyllum secundum; K Kellys Falls population of D. secundum; A 'Avon River' specimen; $\diamond D$. sp. 'Jervis Bay' (Brown 97/80); B Brown 97/83S (shade branch of Brown 97/83), 'Jervis Bay' group; C Brown 97/83, 'Jervis Bay' group; $\otimes D$. sp. 'Lansdowne' (Brown 97/51); F D. fitzgeraldii; $\mathbf{S}$ D. sayeri. 


\section{(3) Dracophyllum sp. 'Jervis Bay' (Brown 97/80)}

Dracophyllum sp. 'Jervis Bay' (Brown 97/80) differs from D. sp. 'Lansdowne' (Brown 97/51) and D. secundum by tending to have larger leaves (llm and lwm: (90-)115-195(-228) $\mathrm{mm}$ and (4.5-)6-8 $\mathrm{mm}$, respectively), blunt leaves and bracts (las and bas, respectively), and more floriferous at the base and midpoint of the inflorescence ( $f s n$ and $f s t:>10$-flowered, often $20-35$, or occasionally with middle nodes having as few as 3 flowers). When compared with $D$. sayeri, this 'Jervis Bay' taxon tends to be a smaller shrub (hab), with narrower and shorter leaves (lwm and $l \mathrm{~lm}$, respectively), but generally with larger flowers ( $\mathrm{anl}, \mathrm{ctl}$, stl: (0.6-)1.4-1.6(-1.8) mm, (4.8-)5.8-6.4(-7.1) $\mathrm{mm}$ and (2.2-)2.5-3.1(-3.3) mm compared with 1-1.4 mm, (3.3-)4.5-4.9 mm and c. $2 \mathrm{~mm}$ in D. sayeri; refer character vector diagram of Fig. 3).

One specimen of the 'Jervis Bay' group (Brown 97/83S; ' $\mathrm{B}$ ' of Figs 2, 3) is a specimen from a lower, shaded branch of Brown $97 / 83$ (' $C$ ' of Figs 2, 3), which has fewer flowers per node. The former collection is intermediate between $D$. secundum sensu stricto and D. sp. 'Jervis Bay' (Brown 97/80) in the ordination space (Figs 2,3). The removal of the character 'flower number at the base of inflorescence' $(f s n)$ from the analysis results in specimen ' $\mathrm{B}$ ' clustering closer to the remainder of the 'Jervis Bay' group (ordination not presented here).

The results of the analyses suggest that D. sp. 'Jervis Bay' (Brown 97/80) is morphologically more similar to $D$. sayeri and $D$. fitzgeraldii than to $D$. secundum sensu stricto (Fig. 4) or D. sp. 'Lansdowne' (Brown 97/51).

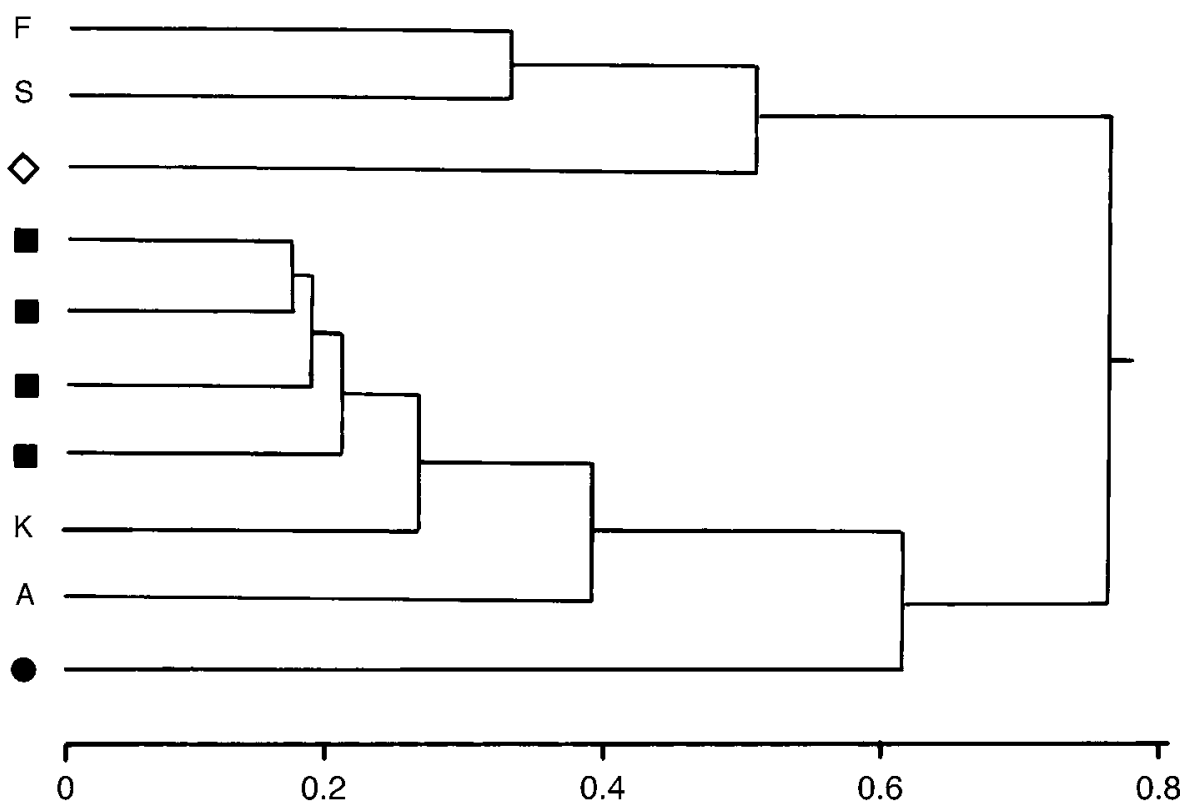

Fig. 4. Simplified flexible UPGMA phenogram generated from agglomerative group fusion using Gower's metric association measure (note: bract and leaf indumentum characters not used). $\otimes$ Dracophyllum secundum; K 3 specimens from Kellys Falls population of D. secundum; A 'Avon River' specimen; $\diamond D$. sp. 'Jervis Bay' (Brown 97/80); $\otimes D$. sp. 'Lansdowne' (Brown 97/51); F D. fitzgeraldii; $\mathbf{S}$ D. sayeri. 


\section{(4) Dracophyllum sp. 'Lansdowne' (Brown 97/51)}

This group is morphologically most similar to D. secundum sensu stricto. It is distinguished from both D. secundum and the 'Jervis Bay' group by several characters, but particularly by its longer floral features. For example, the longer corolla tube and lobes (ctl and cll: 17-22(-24) mm and 2.7-3.8(-4) mm, respectively; cf. (4-)5.6-7.2(-9.2) mm and 1-2(-3) $\mathrm{mm}$ in D. secundum; (4.8-)5.8-6.5(-7) $\mathrm{mm}$ and 1.8-2.3 $\mathrm{mm}$ in 'Jervis Bay' group), calyx lobe length $(\mathrm{klm})$ which is $(8.7-) 9-10(-10.6) \mathrm{mm}$ compared with (3.4-)4-5.2(-6.8) $\mathrm{mm}$ in D. secundum and (5-)5.8-6.6(-7) $\mathrm{mm}$ in 'Jervis Bay' group, and style length (stl) equal to (14.5-)15-19 mm compared with (2-)2.5-4(-7) $\mathrm{mm}$ and (2.2-)2.5-3.1(-3.5) $\mathrm{mm}$. The basipetal maturation of the inflorescence (fma), insertion of the stamens at the base of the corolla (asa), compared with upper half of corolla tube, and generally longer and wider leaves (llm and lwm: (85-)125-155) $\mathrm{mm}$ and (3-)3.5-4 mm compared with D. secundum above) (Fig. 2) also distinguish this species.

\section{(5) Dracophyllum fitzgeraldii}

Many of the features that separate the 'Jervis Bay' group from D. secundum and the 'Lansdowne' group also distinguish $D$. fitzgeraldii from the two latter taxa. For example, D. fitzgeraldii has leaf length (llm) (160-)205-335 mm, leaf width (lwm) (7-)9-11 mm, flower number at the base and midpoint of the inflorescence ( $f s n$ and $f t n)$ $>10$, often 20-35-flowered. Additional features that distinguish between $D$. fitzgeraldii, D. sayeri and D. sp. 'Jervis Bay' (Brown 97/80) include: calyx lobe length $(\mathrm{klm})$ (3.9-)4.4-5 mm compared with 2.8-3.5 $\mathrm{mm}$ in D. sayeri and (5-)5.8-6.6(-7.1) $\mathrm{mm}$ in 'Jervis Bay' group, corolla tube length (ctl) c. $5.3 \mathrm{~mm}$ compared with (3.3-)4.5-4.9 mm in D. sayeri and (4.8-)5.8-6.4(-7.1) $\mathrm{mm}$ in 'Jervis Bay' group, anther position (anp) partially exserted from corolla tube compared with fully exserted in D. sayeri and fully included in the 'Jervis Bay' group, and corolla tube to calyx length ratio (cvk) 0.6 compared with 1 in the two latter taxa.

\section{(6) Dracophyllum sayeri}

The leaves of this species are similar to, albeit larger than, those of $D$. sp. 'Jervis Bay' (Brown 97/80) and D. fitzgeraldii, viz. leaf length (llm) (240-)410-440 mm, leaf width (lwm) 9-11.5 mm. Likewise, flower number ( $f s n$ and $f t n ;>10$, often 20-35 and 4 to at least 10-flowered, respectively), leaf apex (las) and bract apex (bas) help to separate these three taxa from D. secundum and the 'Lansdowne' group. Dracophyllum sayeri tends to have fewer flowers in each axillary spike ( $f s n$ and $f t n ; c .20$ and 4 to at least 10, respectively) than $D$. fitzgeraldii and the 'Jervis Bay' group. The corolla lobes ( $\mathrm{cll}$ ) of $D$. sayeri are also much longer than in the other two taxa, namely 3.5-3.8 mm compared with c. $2.7 \mathrm{~mm}$ in D. fitzgeraldii and 1.8-2.3 $\mathrm{mm}$ in D. sp. 'Jervis Bay' (Brown 97/80).

\section{Conclusion}

Field studies and morphometric analyses permit the following five taxa to be recognised: D. secundum, D. sp. 'Jervis Bay' (Brown 97/80), D. sp. 'Lansdowne' (Brown 97/51), D. fitzgeraldii, and D. sayeri. The results of this study support a narrower circumscription of Dracophyllum secundum than previously applied and the recognition of two new species, namely, D. sp. 'Jervis Bay' (Brown 97/80) and D. sp. 'Lansdowne' (Brown 97/51). These latter two species will be formally described by Brown and Streiber (1999).

The taxonomic status of the 'Avon River' specimen, currently included within D. secundum sensu stricto requires further evaluation based on population studies. 


\section{Acknowledgments}

We thank Martin Krogh (University of New South Wales) for assistance in preliminary data analysis and Darren Crayn (formerly U.N.S.W.) for helpful discussion. We are grateful to Bob Makinson and staff at CANB for their help in data collection. The staff of Booderee National Park, Beecroft Peninsula Firing Range, State Forests of New South Wales (Taree) and Geoff Williams (from Lansdowne, N.S.W.) all assisted us greatly in the collection of material from these areas.

\section{References}

Allan, H.H. (1961) Flora of New Zealand, vol. 1. (Government Press: Wellington).

Belbin, L. (1993) PATN Pattern Analysis Package. Technical reference. (CSIRO Division of Wildlife and Ecology: Canberra).

Briggs, B.G. \& Johnson, L.A.S. (1979) Evolution in the Myrtaceae - evidence from inflorescence structure. Proc. Linn. Soc. New South Wales 102: 157-256.

Brown, E.A. \& Streiber, N. (1999) Systematic studies in Dracophyllum (Epacridaceae) 2. New species of Dracophyllum in New South Wales. Telopea 8: 393-401.

Brown, E.A. \& Wiecek, B.M. (1996) Morphological variation in Leucopogon rufus Lindl.: a preliminary study. Annals of Botany 77: 327-331.

Crayn, D.M., Kron, K.A. \& Quinn, C.J. (1998) Phylogenetics and evolution of epacrids: a molecular analysis using the plastid gene $r b c \mathrm{~L}$ with a reappraisal of the position of Lebetanthus. Austral. J. Bot. 46(2): 187-200.

Crisp, M.D. \& Weston, P.H. (1993) Geographic and ontogenetic variation in morphology of Australian waratahs (Telopea: Proteaceae). Syst. Biol. 42: 49-76.

Fairley, A. \& Moore, P. (1989) Native Plants of the Sydney District. An identification guide. (Kangaroo Press: Kenthurst).

Gower, J.C. (1971) A general coefficient of similarity and some of its properties. Biometrics 27: 857-871.

Oliver, W.R.B. (1929) A revision of the genus Dracophyllum. Trans. E Proc. New Zealand Inst. 59: 678-714.

Powell, J.M. (1992) Epacridaceae. Pp. 401-434 in Harden, G.J. (ed.), Flora of New South Wales, vol. 3. (NSW University Press: Kensington).

Powell, J.M., Crayn, D.M., Gadek, P.A., Quinn, C.J., Morrison, D.A. \& Chapman, A.R. (1996) A re-assessment of the relationships within Epacridaceae. Annals of Botany 77: 305-315.

Virot, R. (1975) Épacridacées. Pp. 5-160 in Aubreville, A. \& Leroy, J.F. (eds), Flore de la NouvelleCalédonie et Dépendances, vol. 6. (Muséum National d'Histoire Naturelle: Paris). 


\section{Appendix 1. Index to collections used in numerical analysis}

Collections are arranged alphabetically by collector's name and, under these, in numerical order. Names of Dracophyllum taxa recognised in this paper

1. D. secundum

2. D. sp. 'Jervis Bay' (Brown 97/80)

3. D. sp. 'Lansdowne' (Brown 97/51)

4. D. fitzgeraldii

5. D. sayeri

Blackshaw s.n. (NSW 411497): 1; Blakely s.n (NSW 411504): 1, (NSW 411505): 1, (NSW 411815): 1; Boden s.n. (NSW 411501): 1; Boorman s.n. (NSW 108893): 1, (NSW 411537): 1; Brown 95/241b: 5, 97/21a, c, e, f: 1, 97/50: 3, 97/51: 3, 97/57a: 3, 97/72a, b: 1, 97/80: 2, 97/81: 2, 97/83: 2, 97/83s: 2, 97/84: 2, 97/87: 2, 97/90: 2, 97/98a: 1.

Cambage 3831: 5; Camfield s.n. (NSW 411244): 1; Cheel s.n. (NSW 411507): 1; Constable s.n. (NSW 52724): 2, (NSW 53360): 1, (NSW 56022): 1; Corbett 124: 1; Corningham s.n. (NSW 429949): 2; Corsini 2: 1; Coveny 9448: 1; Craven 8613: 1; Crayn s.n. (UNSW 23312a): 2; Curry 8677: 1.

Davies 271: 1; De Nardi s.n. (UNSW 22141): 3; Debenham s.n. (NSW 108896): 1.

Fletcher s.n. (NSW 411533): 1; Fuller s.n. (UNSW 23802): 4.

Griffith LSF3: 3

Hames s.n. (NSW 430667): 2; Hoogland 10040: 1.

Johnson 126: 1; Johnson s.n. (NSW 411503): 1.

Kennedy 398: 1; King s.n. (NSW 417108): 4.

Maiden s.n. (NSW 412114): 4; Makinson 131: 1; McGillivray 1425: 1.

Powell 341[a \& b]: 1, 430: 1, 817: 5; Pulley B.R.169: 1, 4114: 1.

Reilly s.n. (UNSW 7640): 1; Rimes 51: 1; Rodway 917: 2.

Thomas s.n. (NSW 363452): 1; Thompson 2372: 1.

Vost s.n. (NSW 411508): 1.

Waterhouse s.n. (UNSW 7478a \& b): 1; Whaite 1072: 1; Wiecek s.n. (UNSW 15616): 2. 
